\title{
Production and Partial Characterization of High Molecular Weight Extracellular $\alpha$-amylase from Thermoactinomyces vulgaris Isolated from Egyptian Soil
}

\author{
M.I. ABOU DOBARA, A.K. EL-SAYED, A.A. EL-FALLAL and N.F. OMAR* \\ Botany Department, Faculty of Science, Mansoura University (Damietta Branch), Egypt
}

Received 14 July 2010, revised 15 January 2011, accepted 20 January 2011

\author{
Abstract
}

\begin{abstract}
Optimizing production of $\alpha$-amylase production by Thermoactinomyces vulgaris isolated from Egyptian soil was studied. The optimum incubation period, temperature and initial $\mathrm{pH}$ of medium for organism growth and enzyme yield were around $24 \mathrm{~h}, 55^{\circ} \mathrm{C}$ and 7.0 , respectively. Maximum $\alpha$-amylase activity was observed in a medium containing starch as carbon source. The other tested carbohydrates (cellulose, glucose, galactose, xylose, arabinose, lactose and maltose) inhibited the enzyme production. Adding tryptone as a nitrogen source exhibited a maximum activity of $\alpha$-amylase. Bactopeptone and yeast extract gave also high activity comparing to the other nitrogen sources $\left(\mathrm{NH}_{4} \mathrm{Cl}, \mathrm{NH}_{4} \mathrm{NO}_{3}, \mathrm{NaNO}_{3}, \mathrm{KNO}_{3}, \mathrm{CH}_{3} \mathrm{CO}_{2} \mathrm{NH}_{4}\right)$. Electrophoresis profile of the produced two $\alpha$-amylase isozymes indicated that the same pattern at about $135-145 \mathrm{kDa}$ under different conditions. The optimum $\mathrm{pH}$ and temperature of the enzyme activity were 8.0 and $60^{\circ} \mathrm{C}$, respectively and enzyme was stable at $50^{\circ} \mathrm{C}$ over 6 hours. The enzyme was significantly inhibited by the addition of metal ions $\left(\mathrm{Na}^{+}, \mathrm{Co}^{2+}\right.$ and $\left.\mathrm{Ca}^{2+}\right)$ whereas $\mathrm{Cl}^{-}$seemed to act as activator. The enzyme was not affected by $0.1 \mathrm{mM}$ EDTA while higher concentration (10 mM EDTA) totally inactivated the enzyme.
\end{abstract}

K e y w ord s: Thermoactinomyces vulgaris, high molecular weight $\alpha$-amylase

\section{Introduction}

Enzymes produced by thermophilic bacteria have been highlighted for their potential as biocatalysts in biotechnology. The importance of this was referred to the general relationship between enzyme thermostability and the thermophilicity of the host bacterium (Herbert, 1992).

The $\alpha$-amylase (EC 3.2.1.1) is a well-known endoamylase that hydrolyzes starch by randomly cleaving internal a- 1,4-glucosidic linkages. The spectrum of $\alpha$-amylase applications has widely used in many fields, such as starch saccharification, textile, food, brewing, distilling industries, medical and analytical chemistries (Pandey et al., 2000). Despite this, interest in new and improved $\alpha$-amylase is growing vastly. Therefore, the search for thermostable $\mathrm{Ca}^{2+}$ independent $\alpha$-amylase (Tonkova, 2006) is continuous. Enzymes of the thermophilic actinomycetes Thermoactinomyces species, especially their $\alpha$-amylase (Ito et al., 2007), have attracted much interest because of their activity at high temperature. The advantages for using thermostable $\alpha$-amylases in industrial processes include the decreased risk of contamination, the increased diffusion rate and the decreased cost of external cooling. In addition, the stability of biocatalysts is often a limiting factor in the selection of enzymes for industrial applications due to the elevated temperature or extreme $\mathrm{pH}$ of many biotechnological processes.

The aim of the investigations was to determine the optimum conditions for production of highly active and industrial stable $\alpha$-amylase by an Egyptian isolate of the thermophilic actinomycete Thermoactinomyces vulgaris and to investigate the enzyme properties.

\section{Experimental}

\section{Materials and Methods}

T. vulgaris strain. $T$. vulgaris strain was isolated from fertile soil samples collected from Egypt at $50^{\circ} \mathrm{C}$ and identified according to Bergey's Manual of Systematic Bacteriology (Lacey and Cross, 1989). The culture was maintained on Czapek-yeast-casein (CYC) agar slants.

* Corresponding author: N.F. Omar, Botany Department, Faculty of Science, Mansoura University (Damietta Branch), New Damietta, Egypt. P.O. Box 34517; e-mail: noha_omar15@yahoo.com 
Production of $\alpha$-amylase. The organism was grown in conical flasks containing starch-nitrate medium (Waksman, 1959) as a basal medium with $\mathrm{pH}$ adjusted to 7.5 . The medium $(20 \mathrm{ml}$ taken in $250 \mathrm{ml}$ Erlenmeyer flasks) was inoculated with $1 \mathrm{ml}$ of spore suspension of pure colonies of the organism and incubated at $50^{\circ} \mathrm{C}$ with shaking $(150 \mathrm{rpm})$ for 72 hours.

The initial $\mathrm{pH}$ of the medium (4.0-10.0), temperature of incubation $\left(30-60^{\circ} \mathrm{C}\right)$, and incubation period $(12-96 \mathrm{~h})$ were tested for $\alpha$-amylase production. Different carbon sources $(1 \%)$ and nitrogen sources (equimolecular nitrogen amounts equivalent to the nitrogen content of the basal medium) were used for optimization of nutritional factors. The various tested carbon sources were: starch, cellulose, glucose, galactose, xylose, arabinose, lactose and maltose. The nitrogen sources were included $\mathrm{NH}_{4} \mathrm{Cl}, \mathrm{NH}_{4} \mathrm{NO}_{3}, \mathrm{NaNO}_{3}$, $\mathrm{KNO}_{3}$, ammonium acetate, bactopeptone, yeast extract and tryptone were tested.

On the compilation of the previous experiments, the cell-free enzyme supernatant was obtained by centrifugation at $8000 \times \mathrm{g}$ for $20 \mathrm{~min}$. Experiments were carried out in triplicate and the results were treated statistically and standard errors are shown.

$\alpha$-Amylase assay. The amylase assay was based on the reduction in blue colour intensity resulting from starch hydrolysis (Palanivelu, 2001). The reaction mixture consisted of $0.4 \mathrm{ml}$ of diluted enzyme, $0.5 \mathrm{ml}$ of $0.1 \%$ soluble starch and $1 \mathrm{ml}$ of phosphate buffer $(0.1 \mathrm{M}, \mathrm{pH} 7)$ was incubated at $50^{\circ} \mathrm{C}$ for 10 minutes. The reaction was stopped by adding $0.5 \mathrm{ml}$ of $0.1 \mathrm{~N}$ $\mathrm{HCl}$ and the colour was developed by adding $0.5 \mathrm{ml}$ of $\left(2 \% \mathrm{KI}\right.$ in $\left.0.2 \% \mathrm{I}_{2}\right)$ solution. The optical density (OD) of the blue colour solution was determined using a Unico 7200 SERIES spectrophotometer at $690 \mathrm{~nm}$. One unit of enzyme activity is defined as the quantity of enzyme that caused $20 \%$ reduction of blue colour intensity of starch iodine solution at reaction incubation temperature in $1 \mathrm{~min}$ per $\mathrm{ml}$.

Intracellular protein content of $T$. vulgaris. The harvested mycelia of $T$. vulgaris strain were used for determination of intracellular protein. Washed pellets were dissolved in $20 \mathrm{ml}$ of $\mathrm{NaOH}(1 \mathrm{M})$, and boiled for 20 minutes. Dilution of clarified solution was used to determine the intracellular protein concentration using Bradford method (1976). Bovine serum albumin was used as standard.

Physicochemical properties of $\alpha$-amylase. Enzyme activity at various temperatures and $\mathrm{pH}$ was studied by incubating reaction mixtures at different temperatures $\left(30-80^{\circ} \mathrm{C}\right)$ and Tris- $\mathrm{HCl}$ buffer $(\mathrm{pH} 4.0-9.0)$. Enzyme stability at various temperatures was also studied by pre-incubating cell-free supernatants for different time $(1-6 \mathrm{~h})$ at various temperatures $\left(50^{\circ} \mathrm{C}-80^{\circ} \mathrm{C}\right)$. The effect of metal salts $\left(\mathrm{NaCl}, \mathrm{CoCl}_{2}\right.$ and $\left.\mathrm{CaCl}_{2}\right)$ and EDTA on activity was determined by adding of different concentrations of each salt to the standard assay. Activities were expressed as a percentage of the maximal activity.

Ammonium sulphate precipitation of the enzyme. The supernatant of culture was brought to $70 \%$ ammonium sulphate saturation in an ice bath. The precipitated protein was collected by centrifugation at $3000 \times \mathrm{g}$ at $4{ }^{\circ} \mathrm{C}$ and dissolved in $1-2$ pellet volumes of phosphate buffer (0.1 M, pH 7.0). The enzyme solution was dialyzed overnight at $4^{\circ} \mathrm{C}$ against the same buffer then concentrated over sucrose bed. The final enzyme solution was taken for polyacrylamide gel electrophoresis (PAGE).

Electrophoresis and molecular weight determination. Nondenaturing PAGE was carried out by omitting SDS from the method of Laemmli (1970) with $10 \%$ polyacrylamide. The reference pre-stained protein marker (Molecular weights 10 to $170 \mathrm{kDa}$, SM 0671, Fermentas) was used. Amylase activity of proteins was detected according to Garcia-Gonzalez et al., (1991) by incubating the gels at $50^{\circ} \mathrm{C}$ for $20 \mathrm{~min}$ in $0.2 \mathrm{M}$ phosphate buffer ( $\mathrm{pH} 7.0$ ) containing $2 \%$ starch and then immersing in staining solution (KI $13 \mathrm{~g} / \mathrm{l}$ and $\left.\mathrm{I}_{2} 6 \mathrm{~g} / \mathrm{l}\right)$. The gel was destained with distilled water. The stain was stable for only a few minutes.

Statistical analysis. Data were statistically analyzed for variance and the least significant difference (LSD at 0.01 level) using one-way analysis of variance (ANOVA). A software system SPSS version 15 was used.

\section{Results}

The production of $\alpha$-amylase by T. vulgaris increased significantly during the growth of the organism, with the maximum production after 24 hours $(1.03 \pm 0.09 \mathrm{U} / \mathrm{ml})$. After 36 hours the activity was reduced rapidly by $72.8 \%$ (Fig. 1). Although there was

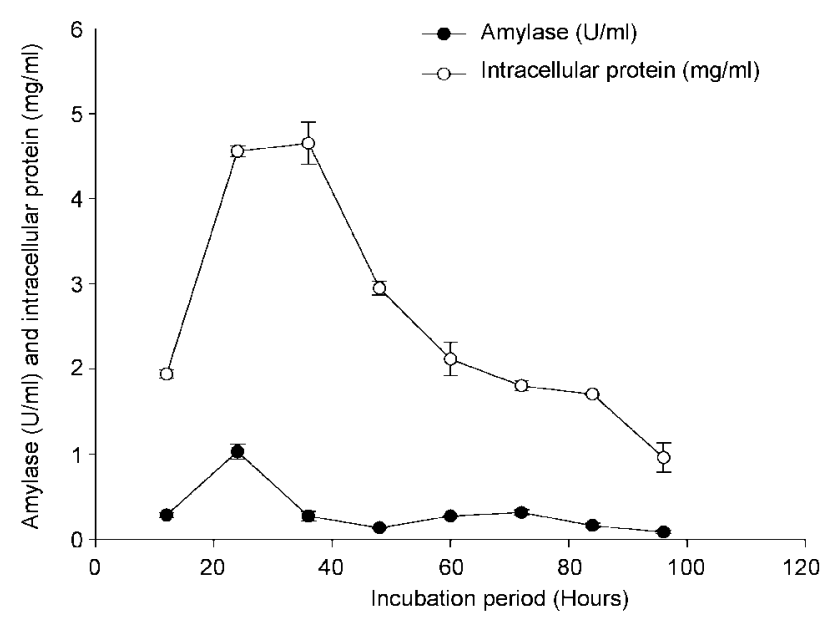

Fig. 1. Effect of incubation period on growth and $\alpha$-amylase production by $T$. vulgaris grown in starch-nitrate medium containing $1.0 \%$ starch. 


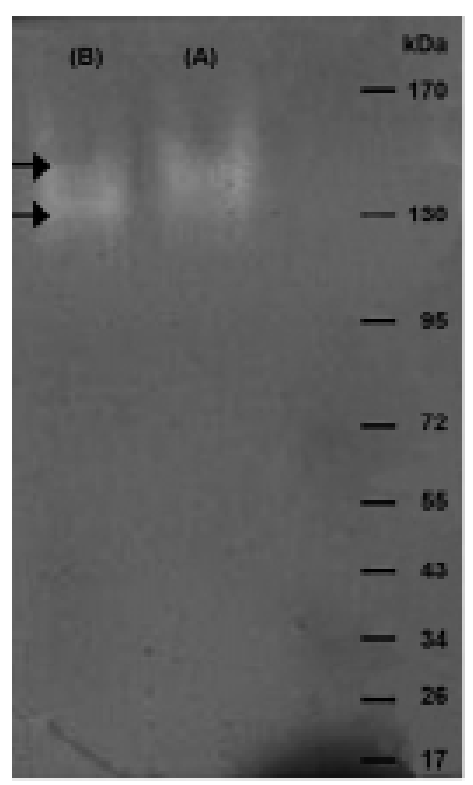

Fig. 2. Active-PAGE of $\alpha$-amylase profile of T. vulgaris grown in starch-nitrate medium containing $1.0 \%$ starch after 24 hours (A), and 72 hours (B).

Arrows indicate the position of the two $\alpha$-amylase isozymes of approximate size between $135-145 \mathrm{kDa}$.

a significant increase in the production after 72 hours, the $\alpha$-amylase profile; on active PAGE didn't differ from that at 24 hours (Fig. 2) as they produce two $\alpha$-amylase isozymes with approximate molecular weight $135-145 \mathrm{kDa}$.

The optimum temperatures for the production of $\alpha$-amylase were in the range $45^{\circ} \mathrm{C}$ to $55^{\circ} \mathrm{C}$ with non significant difference in this range. Below $45^{\circ} \mathrm{C}$, the organism could grow weakly but no activity could be detected (Fig. 3).

Maximum production occurred in the $\mathrm{pH}$ range of 6.0 to $7.0(3.5 \mathrm{U} / \mathrm{ml})$, increasing the $\mathrm{pH}$ above 7.0 induced a significant decrease in the yield. At $\mathrm{pH} 10.0$

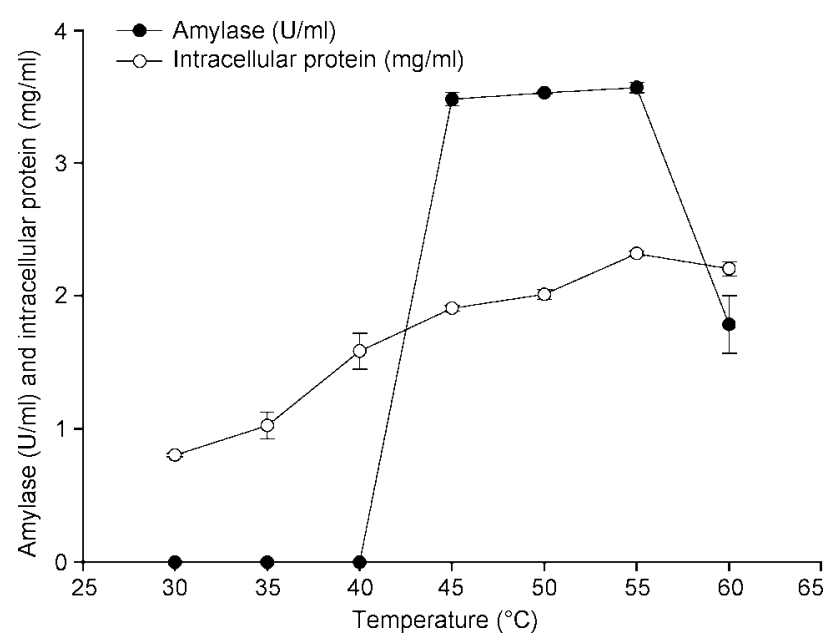

Fig. 3. Effect of temperature on growth and $\alpha$-amylase production by $T$. vulgaris grown in starch-nitrate medium containing $1.0 \%$ starch.

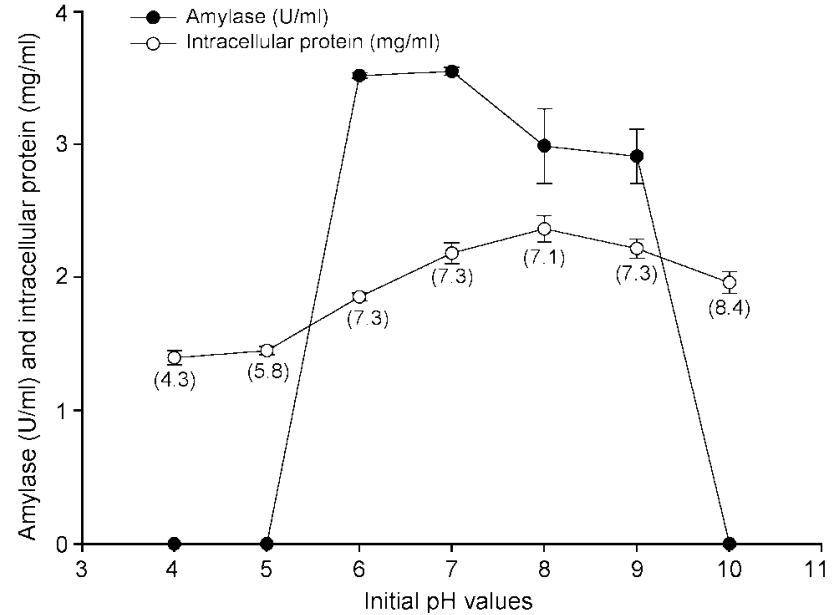

Fig. 4. Effect of $\mathrm{pH}$ on growth and $\alpha$-amylase production by $T$. vulgaris grown in starch-nitrate medium containing $1.0 \%$ starch

( ) denotes the final $\mathrm{pH}$.

and below $\mathrm{pH} 6$, the production of the enzyme was completely inhibited (Fig. 4).

T. vulgaris was able to grow well using different carbon sources $(1 \% \mathrm{w} / \mathrm{v})$, namely, starch, cellulose, glucose, galactose, xylose, arabinose, lactose and maltose. However, the used carbon sources other than starch induced an extremely significant decrease in the enzyme yield (Table I). Although different carbon sources affected the quantity of the enzyme production, it didn't affect its isozymal pattern as they produced the same two $\alpha$-amylase isozymes of approximate molecular weight 135-145 kDa (data not shown).

Tryptone, bactopeptone, yeast extract and $\mathrm{NH}_{4} \mathrm{Cl}$ caused a highly significant increasing in enzyme production comparing with $\mathrm{KNO}_{3}$ of the basal medium (Table II). The highest production of $\alpha$-amylase $(93.81 \pm 0.20 \mathrm{U} / \mathrm{ml})$ was recorded with tryptone and the lowest $(1.86 \pm 0.16)$ was recorded with $\mathrm{NaNO}_{3}$. The different used nitrogen sources $\left(\mathrm{NH}_{4} \mathrm{Cl}, \mathrm{NH}_{4} \mathrm{NO}_{3}\right.$, $\mathrm{NaNO}_{3}, \mathrm{KNO}_{3}$, ammonium acetate, bactopeptone, yeast

Table I

Effect of carbon sources on growth and $\alpha$-amylase production by $T$. vulgaris grown in starch-nitrate medium containing different carbon sources instead of starch

\begin{tabular}{|l|c|c|}
\hline $\begin{array}{c}\text { Carbon sources } \\
(1.0 \%)(\mathrm{w} / \mathrm{v})\end{array}$ & $\begin{array}{c}\text { Amylase } \\
(\mathrm{U} / \mathrm{ml})\end{array}$ & $\begin{array}{c}\text { Intracellular protein } \\
(\mathrm{mg} / \mathrm{ml})\end{array}$ \\
\hline Starch & $3.43 \pm 0.02$ & $1.06 \pm 0.04$ \\
\hline Glucose & $0.04 \pm 0.02$ & $0.78 \pm 0.02$ \\
\hline Galactose & $0.02 \pm 0.01$ & $0.86 \pm 0.08$ \\
\hline Xylose & $0.10 \pm 0.06$ & $0.76 \pm 0.02$ \\
\hline Arabinose & $0.07 \pm 0.02$ & $0.76 \pm 0.01$ \\
\hline Lactose & $0.11 \pm 0.02$ & $0.63 \pm 0.02$ \\
\hline Maltose & $0.36 \pm 0.05$ & $0.71 \pm 0.04$ \\
\hline Cellulose & $0.05 \pm 0.03$ & $0.52 \pm 0.01$ \\
\hline
\end{tabular}

\pm standard error 
Table II

Effect of nitrogen sources on growth and $\alpha$-amylase production by $T$. vulgaris grown in starch-nitrate medium containing different nitrogen sources instead of $\mathrm{KNO}_{3}$

\begin{tabular}{|l|c|c|c|}
\hline Nitrogen sources & Final PH & $\begin{array}{c}\text { Amylase } \\
(\mathrm{U} / \mathrm{ml})\end{array}$ & $\begin{array}{c}\text { Intracellular } \\
\text { protein }(\mathrm{mg} / \mathrm{ml})\end{array}$ \\
\hline Ammonium acetate & 6.71 & $1.06 \pm 0.15$ & $6.46 \pm 0.11$ \\
\hline Tryptone & 6.75 & $1.10 \pm 0.12$ & $93.81 \pm 0.20$ \\
\hline Yeast extract & 6.87 & $0.72 \pm 0.03$ & $45.29 \pm 0.08$ \\
\hline Bactopeptone & 6.64 & $0.93 \pm 0.07$ & $63.05 \pm 0.63$ \\
\hline $\mathrm{NH}_{4} \mathrm{Cl}$ & 6.46 & $0.66 \pm 0.06$ & $21.56 \pm 3.64$ \\
\hline $\mathrm{NH}_{4} \mathrm{NO}_{3}$ & 6.40 & $0.95 \pm 0.03$ & $6.34 \pm 0.17$ \\
\hline $\mathrm{NaNO}_{3}$ & 6.81 & $0.80 \pm 0.01$ & $1.86 \pm 0.16$ \\
\hline $\mathrm{KNO}_{3}$ & 6.73 & $0.53 \pm 0.02$ & $3.54 \pm 0.01$ \\
\hline
\end{tabular}

\pm standard error

extract and tryptone) didn't have any effect on the enzyme electrophoretic profile. The $\alpha$-amylase profile had the same previous pattern of two $\alpha$-amylase isozymes at about $135-145 \mathrm{kDa}$ (data not shown).

Physicochemical properties of $\alpha$-amylase. The $\alpha$-amylase activity couldn't be detected at $\mathrm{pH} 4.0$ but it increased significantly with the increase of the $\mathrm{pH}$ until it reaches its optimum point at $\mathrm{pH} 8.0$ (Fig. 5). The optimum activity occurred at temperature range between $50^{\circ} \mathrm{C}$ and $60^{\circ} \mathrm{C}$, with an optimum point of $60^{\circ} \mathrm{C}$ (Fig. 5). The minimum level of the activity $(54.4 \pm 2.3 \mathrm{U} / \mathrm{ml})$ was occurred at $80^{\circ} \mathrm{C}$.

The enzyme was stable at $50^{\circ} \mathrm{C}$ retaining about $80 \%$ of its activity over 6 hours incubation period, but at higher temperature the activity of the enzyme declined (Fig. 6). At $60^{\circ} \mathrm{C}$ and $70^{\circ} \mathrm{C}$, the enzyme has a half-life of about one hour. However, at $80^{\circ} \mathrm{C}$ it retained more than $20 \%$ of its activity up to 4 hours. At $90^{\circ} \mathrm{C}$ the enzyme lost its activity rapidly.

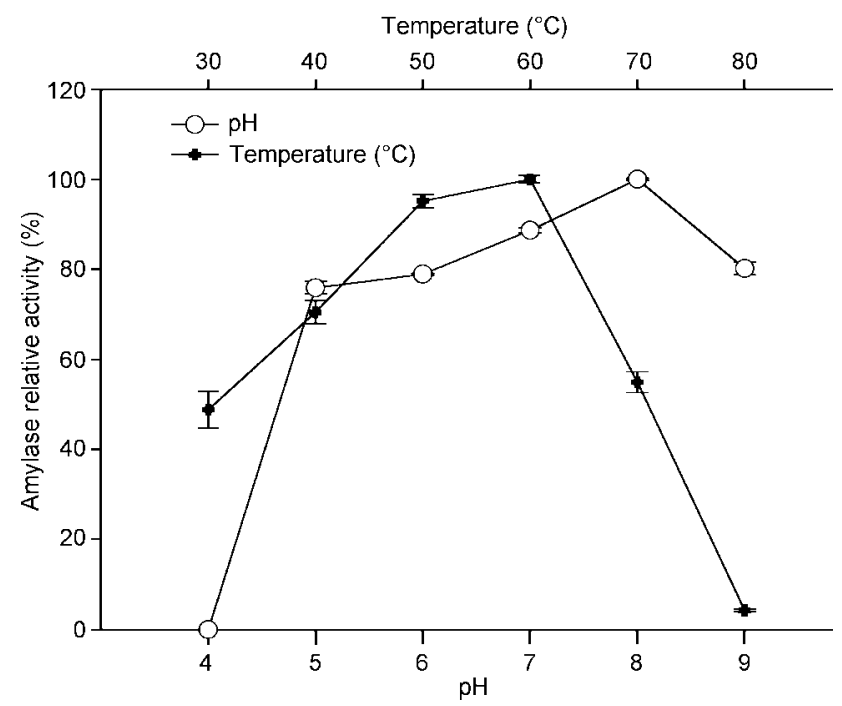

Fig. 5. Effect of temperature and $\mathrm{pH}$ on $\alpha$-amylase activity. The enzyme activities are represented relative to the maximal value.
Table III

Effect of various EDTA concentrations on $\alpha$-amylase activity. The enzyme activities are represented relative to the control activity

\begin{tabular}{|c|c|}
\hline Concentration of EDTA $(\mathrm{mM})$ & Amylase relative activity (\%) \\
\hline 0.001 & $99.62 \pm 4.46$ \\
\hline 0.01 & $104.36 \pm 1.70$ \\
\hline 0.1 & $108.85 \pm 0.10$ \\
\hline 0.5 & $53.59 \pm 0.52$ \\
\hline 1 & $18.81 \pm 5.78$ \\
\hline 5 & $1.12 \pm 0.70$ \\
\hline 10 & $0.00 \pm 0$ \\
\hline
\end{tabular}

\pm standard error

The enzyme was significantly influenced by the different metal salts including $\mathrm{NaCl}, \mathrm{CoCl}_{2}$ and $\mathrm{CaCl}_{2}$ (Fig. 7). $\mathrm{CoCl}_{2}$ induced significant inhibition of the enzyme activity. An amount of $1 \mathrm{mM}$ of $\mathrm{NaCl}$ and $\mathrm{CaCl}_{2}$ caused extremely significant decrease in enzyme

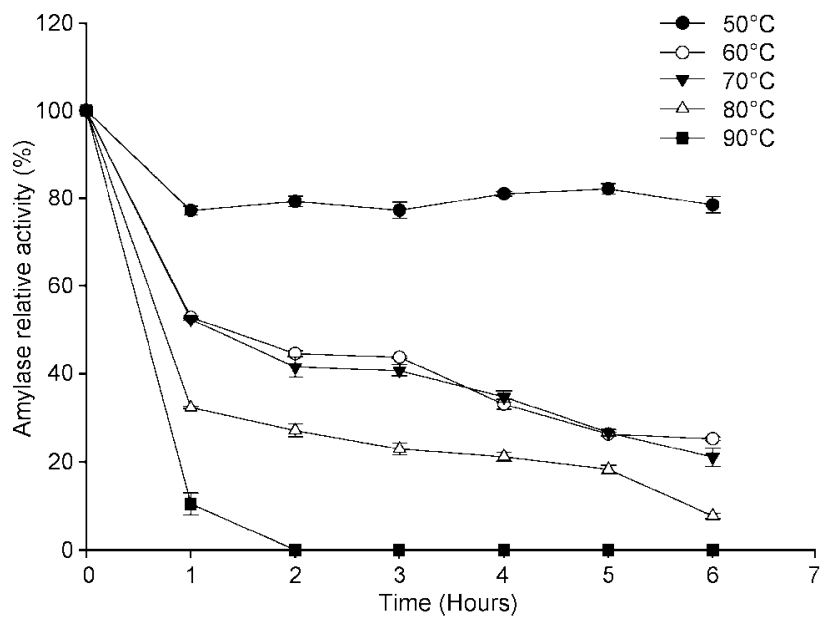

Fig. 6. Effect of temperature on the stability of $\alpha$-amylase. The enzyme activities are represented relative to the maximal value.

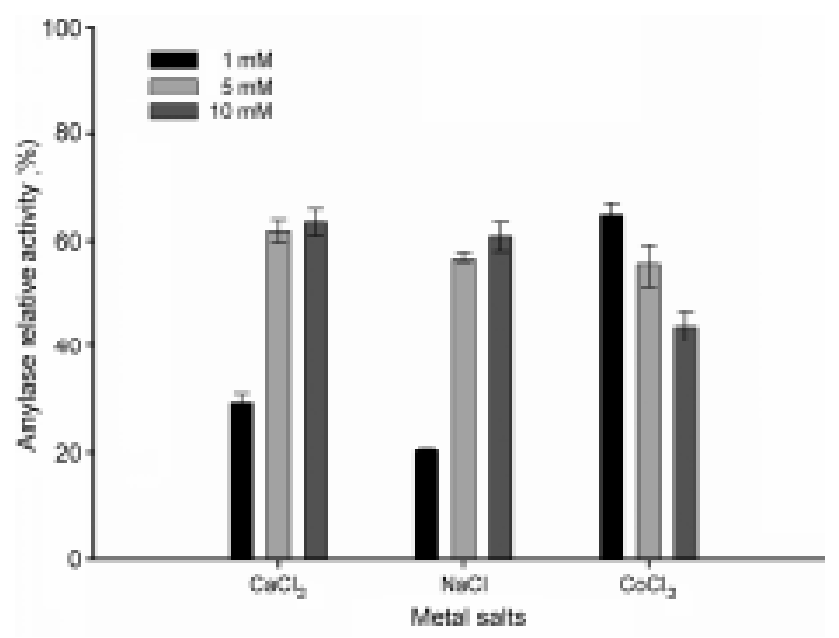

Fig. 7. Effect of various metal salts concentrations on $\alpha$-amylase activity.

The enzyme activities are represented relative to the control activity. 
activity by about $80 \%$ and $70 \%$ respectively. However, increasing of their concentration up to $10 \mathrm{mM}$ of $\mathrm{NaCl}$ and $\mathrm{CaCl}_{2}$ resulted in retaining $60.8 \%$ and $63.4 \%$ of its activity respectively. The enzyme activity was not affected by $0.001,0.01$ and $0.1 \mathrm{mM}$ EDTA but it was totally inactivated by $10 \mathrm{mM}$ EDTA (Table III). On the other hand, $0.5 \mathrm{mM}$ EDTA was found to decrease the activity to $53.6 \%$ comparing with the control $\left(96.6 \mathrm{Uml}^{-1}\right)$.

\section{Discussion}

$\alpha$-Amylases have been isolated from diversified sources including plants, animals, and microbes, where they play a dominant role in carbohydrate metabolism. In spite of the wide distribution of $\alpha$-amylase, microbial sources are used for the industrial production. This is due to their advantages such as cost effectiveness, consistency, less time and space required for production, and ease of process modification and optimization (Lonsane and Ramesh, 1990). Growth expressed as intracellular protein and $\alpha$-amylase production by the thermophilic actinomycete Thermoactinomyces vulgaris reached maximum values after $24 \mathrm{hrs}$, after which, the activity was reduced rapidly by $72.8 \%$. This might be corresponding to the rapid autolysis of Thermoactinomyces species (Lacey, 1971). However, it increased significantly at 60 and 72 hours. After $72 \mathrm{hrs}$, the production decreased gradually and reached its minimum recorded level at 96 hours. As the isozymal pattern was the same at $24 \mathrm{hrs}$ and $72 \mathrm{hrs}$, the observed peaking and troughing of the production can be attributed to differential inhibition by products of substrate hydrolysis rather than the isozymes down or over expression. In support, studies on both glucoamylase and $\alpha$-amylase indicate that inhibition does not occur below a critical concentration of product (Wang et al., 2006). These results indicated that the production of extracellular $\alpha$-amylase by $T$. vulgaris was growth associated and this is in agreement with other investigators (Kuo and Hartman, 1966; Shimizu et al., 1978; Murthy et al., 2009; Asoodeh et al., 2010).

The influence of temperature on amylase production is related to the growth of the organism. The present results revealed an optimum yield of $\alpha$-amylase at $45^{\circ} \mathrm{C}$ to $55^{\circ} \mathrm{C}$. In spite of the relative good growth of the organism at $40^{\circ} \mathrm{C}, \alpha$-amylase activity couldn't be detected. This referred to the action of protease; that is rapidly inactivated at higher temperature (Behnke et al., 1982), which suppresses the amylolytic activity.

The $\mathrm{pH}$ change of the growth medium not only affected the growth and $\alpha$-amylase secretion of $T$. vulgaris but also influence the enzyme stability in the medium. Therefore, the difference of the final $\mathrm{pH}$ of the medium from $\mathrm{pH} 10.0$ to $\mathrm{pH} 6.0$ could explain the complete inhibition of the enzyme activity at $\mathrm{pH} 10.0$ in contrast to the optimum production at $\mathrm{pH} 6.0$ in spite of the same ability of the organism to grow.

The results confirms the inducibility nature of the $\alpha$-amylase when different carbon sources were used and compared. In support, starch is known to induce amylase production in different bacterial strains (Aiyer, 2004; Ryan et al., 2006; Asoodeh et al., 2010). The $\alpha$-amylase production is also appeared to be subjected to catabolite repression by maltose and glucose, like most other inducible enzymes that are affected by substrate hydrolytic products (Bhella and Altosaar, 1985; Morkeberg et al., 1995). Other carbon sources have been found to be strongly repressive although they supported good growth.

Among nitrogen sources, organic nitrogen sources have been preferred for the production of $\alpha$-amylase, with ammonium acetate as an exception. It was recorded that organic nitrogen sources supported maximum $\alpha$-amylase production by various bacteria and fungi due to their high nutritional amino acids and vitamins content (Gupta et al., 2003). The role of amino acids and vitamins in enhancing the $\alpha$-amylase production in different microorganisms have been reported to be highly variable (Gupta et al., 2003). Tryptone was the best nitrogen source that increased the productivity of $\alpha$-amylase by 26.5 fold comparing to $\mathrm{KNO}_{3}$. Ammonium chloride induced a significant increase in the enzyme yield that is higher than that of the ammonium acetate. Similar effect of ammonium chloride was obtained for $B$. subtilis DM-03 (Das et al., 2004). Although the different nitrogen sources had a variable effect on $\alpha$-amylase activity, they did not produce different isozymal profile. This indicate that they have no effect on the isozymal $\alpha$-amylase over expression.

Most raw starch degrading enzymes had optimum $\mathrm{pH}$ in the acidic to neutral range (Pandey et al., 2000; Sun et al., 2010). In the present work, $\alpha$-amylase from T. vulgaris showed a $\mathrm{pH}$ activity profile with a flat top which retaining more than $75 \%$ of the enzyme activity in the $\mathrm{pH}$ range 5.0-9.0, despite it was completely inhibited at $\mathrm{pH}$ 4.0. This $\mathrm{pH}$ profile could be attributed to the limitation of the enzyme catalysis by protonation of the nucleophile at low $\mathrm{pH}$ and by deprotonation of the hydrogen donor at high $\mathrm{pH}$ values (Nielsen et al., 2001). At reaction temperature of $60^{\circ} \mathrm{C}$, the enzyme expresses maximum activity whereas it showed less than $50 \%$ of its activity at $30^{\circ} \mathrm{C}$. This reduced activity might be attributed to the reduced molecular flexibility of the thermophilic protein under mesophilic conditions. Although the enzyme showed only $4 \%$ of its activity at $80^{\circ} \mathrm{C}$, it showed more than $20 \%$ of its activity at $50^{\circ} \mathrm{C}$ after being kept at $80^{\circ} \mathrm{C}$ for $4 \mathrm{hrs}$ indicating inhibition of the enzyme catalysis 
at $80^{\circ} \mathrm{C}$ rather than inactivation of the enzyme. In general, $\alpha$-amylase from $T$. vulgaris, in the present work, is fairly stable at $50^{\circ} \mathrm{C}$ over $6 \mathrm{hrs}$ and with a half-life of about one hour at both $60^{\circ} \mathrm{C}$ and $70^{\circ} \mathrm{C}$.

It is proposed that $\alpha$-amylases belong to a new class of metallo-enzymes characterized by a prosthetic group, i.e., an alkaline-earth metal rather than a transition element, and which plays primarily a structural role (Prakash and Jaiswal, 2010). At different concentration of $\mathrm{CoCl}_{2}$, a significant inhibition in the enzyme activity was recorded. The $\mathrm{Co}^{2+}$ effect was explained by Leveque et al., (2000) to be a result of competition between the exogenous cations and the protein-associated cation. In spite of the important role of both calcium and sodium ions to retain the structure and function of $\alpha$-amylases (Prakash and Jaiswal, 2010), $\alpha$-amylase in the present study was strongly inhibited by both $1 \mathrm{mM} \mathrm{CaCl}_{2}$ and $\mathrm{NaCl}$. Similar inhibitory effect of $\mathrm{CaCl}_{2}$ was reported to amylase of Aspergillus oryzae EI 212 (Kundu et al., 1973). Calcium independent $\alpha$-amylase is suitable for the manufacture of fructose syrup, where $\mathrm{Ca}^{2+}$ is an inhibitor of glucose isomerase (Tonkova, 2006).

Increasing the concentration of $\mathrm{CaCl}_{2}$ and $\mathrm{NaCl}$ was found to retain the enzyme activity, assuming that $\mathrm{Cl}^{-}$ion has a stabilizing role. Chloride ions have been found mainly in the active site of mammalian $\alpha$-amylases, which have been shown to enhance the catalytic efficiency of the enzyme (Prakash and Jaiswal, 2010). In accordance with retaining the enzyme activity at high concentration of $\mathrm{CaCl}_{2}$ and $\mathrm{NaCl}$, the enzyme yield when using ammonium chloride was found to be 3.3 fold of that using other sources of ammonium i.e., $\mathrm{NH}_{4} \mathrm{NO}_{3}$ and ammonium acetate. Regarding to the effect of EDTA, the enzyme retained almost $100 \%$ activity when $0.1 \mathrm{mM}$ EDTA was added to the reaction mixture. But $0.5 \mathrm{mM}$ EDTA inhibited the enzyme activity retaining only $53 \%$ of its activity. The inhibitory effect of EDTA was also documented by many studies (Gupta et al., 2003). Although the molecular weights of microbial $\alpha$-amylases are usually range between 50 to $60 \mathrm{kDa}$ (Vihinen and Mantsala, 1989), the present result revealed a highly molecular weight of two $\alpha$-amylase isozymes $(135-145 \mathrm{kDa})$. In support, Thermoactinomyces vulgaris R-47 was reported to produce two $\alpha$-amylases, TVAI and TVAII with molecular weights of $71 \mathrm{kDa}$ and $67.5 \mathrm{kDa}$ respectively (Ohtaki et al., 2003). However, molecular weight of some $\alpha$-amylases was found to rise owing to carbohydrate moieties (Gupta et al., 2003). In conclusion, the present results indicated a new active highly molecular weight, thermostable and calcium independent $\alpha$-amylase of $T$. vulgaris which could be of importance for the starch-processing industries. Further work is in progress to purify the $\alpha$-amylase of $T$ vulgaris and characterize the purified enzyme.

\section{Literature}

Aiyer P.V.D. 2004. Effect of C: N ratio on alpha amylase production by Bacillus licheniformis SPT 27. African J. Bacteriol. 3: 519-522. Asoodeh A., J. Chamanic and M. Lagzian. 2010. A novel thermostable, acidophilic $\alpha$-amylase from a new thermophilic "Bacillus sp. Ferdowsicous" isolated from Ferdows hot mineral spring in Iran: Purification and biochemical characterization Int. J. Biol. Macromol. doi:10.1016/j.ijbiomac.2010.01.013

Behnke U., H. Ruttloff and R. Kleine. 1982. Preparation and characterization of proteases from Thermoactinomyces vulgaris. $\mathrm{V}$. Investigations on autolysis and thermostability of the purified protease. Z. Allg. Mikrobiol. 22: 511-519.

Bhella R.S. and I. Altosaar. 1985. Purification and some properties of the extracellular $\alpha$-amylase from Aspergillus awamori. Can. J. Microbiol. 31: 149.

Bradford M.M. 1976. A rapid and sensitive method for the quantitation of microgram quantities of protein utilizing the principle of protein dye binding. Anal. Biochem. 72: 248-254.

Das K., R. Doley and A.K. Mukherjee. 2004. Purification and biochemical characterization of thermostable, alkaliphilic, extracellular $\alpha$-amylase from $B$. subtilis DM-03, a strain isolated from the traditional food of India. Biotechnol. Appl. Biochem. 40: 291-298. Garcia-Gonzalez M.D., J.F. Martin, T. Vigal and P. Liras. 1991. Characterization, expression in Streptomyces lividans, and processing of the amylase of Streptomyces griseus IMRU 3570: Two different amylases are derived from the same gene by an intracellular processing mechanism. J. Bacteriol. 173: 2451-2458.

Gupta R., G. Paresh, H. Mohapatra, V.K. Goswami and B. Chauhan. 2003 Microbial $\alpha$-amylases: a biotechnological perspective. Process Biochem. 38: 1599-1616.

Herbert R. A. 1992. Molecular biology and biotechnology of extremophiles. Herbert R.A. and T.J. Sharp (eds). Blackie, Glasgow and London, pp. 1-43.

Ito K., S. Ito, k. Ishino, A. Shimizu-Ibuka and H. Sakai. 2007. Val326 of Thermoactinomyces vulgaris R-47 amylase II modulates the preference for alpha-(1,4)- and alpha-(1,6)-glycosidic linkages. Biochimica et Biophysica Acta 1774: 443-449.

Kundu A.K., S. Das and T.K. Gupta. 1973. Influence of culture and nutritional conditions on the production of amylase by the submerged culture of Aspergillus oryzae. J. Ferment. Technol. 51:142-150.

Kuo M.J. and P.A. Hartman. 1966. Isolation of amylolytic strains of Thermoactinomyces vulgaris and production of thermophilic actinomycete amylases. J. Bacteriol. 92:723-726.

Lacey J. 1971. Thermoactinomyces sacchari sp. nov., a thermophilic actinomycete causing bagassosis. J. Gen. Microbiol. 66: 327-338. Lacey J. and T. Cross. 1989. Genus Thermoactinomyces Tsiklinsky 1899, 501AL. pp. 2574-2585. In: Williams S.T., M.E. Sharpe and J.G. Holt (eds). Bergey's Manual of Systematic Bacteriology, vol. 4. Baltimore, Williams \& Wilkins.

Laemmli U.K. 1970. Cleavage of structural proteins during the assembly of the head of bacteriophage T4. Nature 227: 680-685. Leveque E., S. Janecek, B. Haye and A. Belarbi. 2000. Thermophilic archaeal amylolytic enzymes. Enzyme Microbiol. Technol. 26: 3-14.

Lonsane B.K. and M.V. Ramesh (eds). 1990. Production of bacterial thermostable $\alpha$-amylase by solid state fermentation: a potential tool for achieving economy in enzyme production and starch hydrolysis. pp. 1-56. In: Advances in applied microbiology, vol. 35. San Diego: California Academic Press.

Morkeberg R., M. Carlsen and J. Neilsen. 1995. Induction and repression of $\alpha$-amylase production in batch and continuous cultures of Aspergillus oryzae. Microbiology. 141: 2449-2454.

Murthy P.S., M.M. Naidu and P. Srinivas. 2009. Production of $\alpha$-amylase under solid-state fermentation utilizing coffee waste. J. Chem. Technol. Biotechnol. 84: 1246-1249. 
Nielsen J., T. Borchert and G. Vriend. 2001. The determinants of $\alpha$-Amylase pH-activity profiles. Protein Engineering 14: 505-512.

Ohtaki A., A. Iguchi, M. Mizuno, T. Tonozuka, Y. Sakano and S. Kamitori. 2003. Mutual conversion of substrate specificities of Thermoactinomyces vulgaris R-47 $\alpha$-amylases TVAI and TVAII by site-directed mutagenesis. Carbohydrate Research 338: 1553-1558.

Palanivelu P. 2001. Analytical Biochemistry and separation Techniques. Kalamani Printers, Madurai, India.

Pandey A., P. Nigam, C.R. Soccol, V.Y. Soccol, D. Singh and R. Mohan. 2000. Advances in microbial amylases. Biotechnol. Appl. Biochem. 31: 135-152.

Prakash O. and N. Jaiswal. 2010. $\alpha$-amylase: An ideal representative of thermostable enzymes. Appl. Biochem. Biotechnol. DOI 10.1007/s12010-009-8735-4

Ryan S.M., G.F. Fitzerald and D. Sinderen. 2006. Screening and identification of starch-, amylopectin-, and pullulan-degrading activities in Bifidobacterial strains. Appl. and Environmen. Microbiol. 72: 5289-5296.
Shimizu M., M. Kanno, M. Tamura and M. Suckane. 1978. Purification and some properties of a novel $\alpha$-amylase produced by a strain of Thermoactinomyces vulgaris. Agric. Biol. Chem. 42: 1681-1688.

Sun H., P. Zhao, X. Ge, Y. Xia, Z. Hao, J. Liu and M. Peng. 2010. Recent advances in microbial raw starch degrading enzymes. Appl. Biochem. Biotechnol. 160: 988-1003.

Tonkova A. 2006. Microbial starch converting enzymes of the $\alpha$-Amylase family. In: Ray R.C. and wards O.P. (eds.), pp. 421-472, Microbial Biotechnology in Horticulture, Science Publishers, Enfield, New Hampshire, USA.

Vihinen M. and P. Mantsala. 1989. Microbial amylolytic enzymes. Crit. Rev. Biochem. Mol. Biol. 24: 329-418.

Waksman S.A. 1959. Strain specificity and production of antibiotic substances. X. characterization and classification of species within the Streptmyces griseus Group. Proc. Natl. Acad. Sci. USA 45: 1043-1047.

Wang J.P., A.W. Zeng, Z. Liu and X.G. Yuan. 2006. Kinetics of glucoamylase hydrolysis of corn starch. J. Chem. Techn. and Biotechn. 81: 727-729. 